\title{
Pengembangan Bahan Ajar Data Mining Menggunakan Four-D Model dalam Kerangka Kerja CDIO
}

\author{
Nurroby Wahyu Saputra, Aji Prasetya Wibawa, Utomo Pujianto, \\ Prananda Anugrah
}

Universitas Negeri Malang, Jl. Semarang No.5 Kota Malang 65145, Indonesia

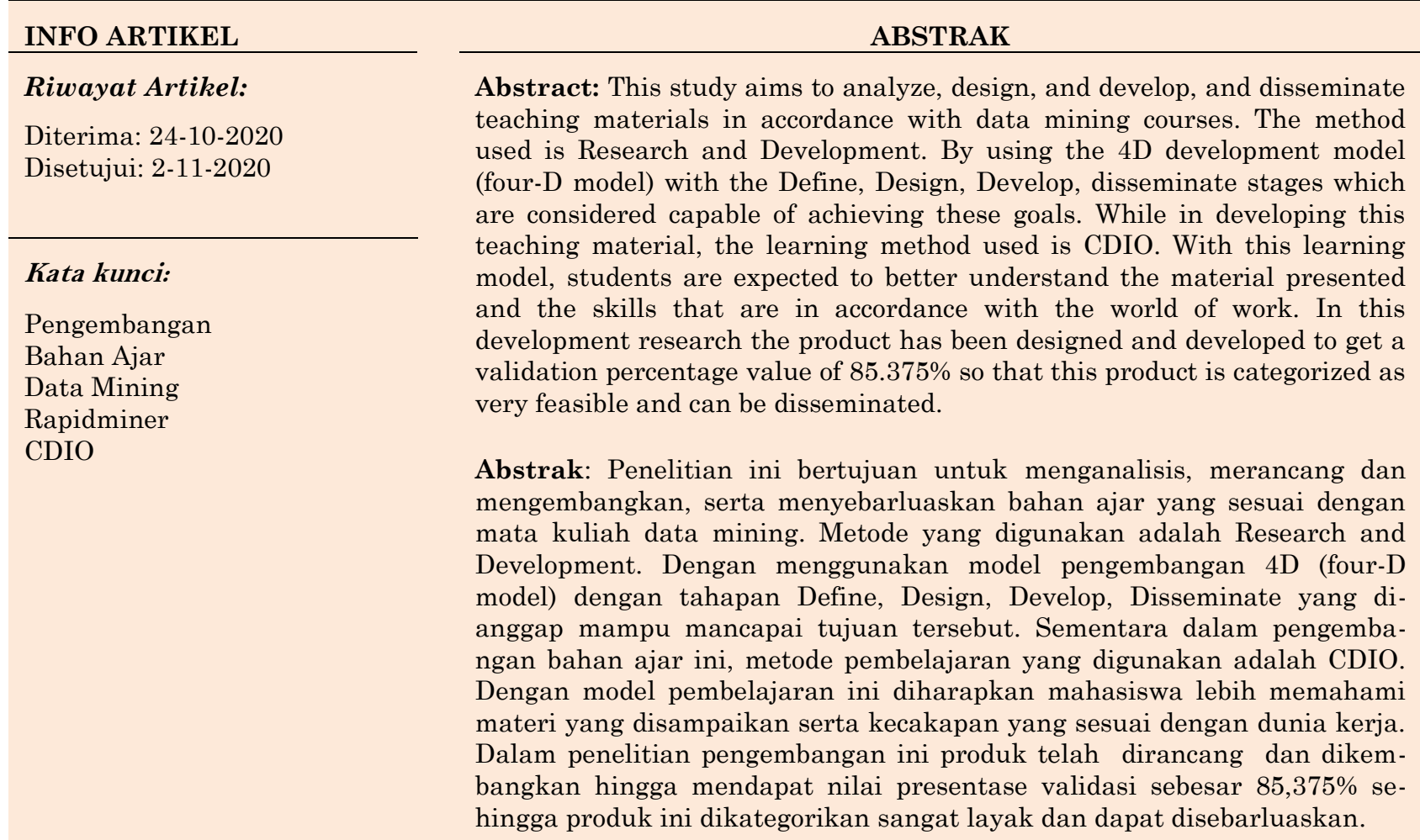

\section{Alamat Korespondensi:}

Utomo Pujianto

Universitas Negeri Malang

Jl. Semarang No.5 Kota Malang 65145, Indonesia

Alamat Instansi/Perguruan Tinggi

E-mail: utomo.pujianto.ft@um.ac.id

\section{PENDAHULUAN}

Bahan ajar merupakan salah satu faktor penting dalam efektifitas sebuah pembelajaran, terlebih pada jenjang Perguruan Tinggi. Kurangnya bahan ajar tentunya dapat mempengaruhi kualitas dari suatu pembelajaran. Dalam konteks pendidikan pada Perguruan Tinggi, masalah umum yang sering dihadapi oleh mahasiswa salah satunya adalah masih belum tercapainya prestasi belajar yang diharapkan. Hal ini dapat dikarenakan kurangnya bahan ajar yang sesuai dengan gaya belajar pada mahasiswa serta terdapat beberapa 
topik materi yang dirasa sulit bagi pengajar dalam menyampaikan materi agar penyampaiannya dapat dipahami dengan baik oleh peserta didiknya (Bahtiar, 2015).

Dalam ilmu komputer, data mining merupakan proses menemukan pola dan pengetahuan dari kumpulan data dengan jumlah yang besar (Jurusan Teknik Elektro, 2019). Dalam penerapannya saat ini data mining merupakan salah satu disiplin ilmu yang sangat diperlukan untuk data mining merupakan salah satu matakuliah keahlian berkarya pilihan (MBKP) yang terdapat pada program studi S1 Teknik Informatika Universitas Negeri Malang. Dalam penerapannya, proses pembelajaran data mining pada program studi S1 Teknik Informatika telah diajarkan sejak tahun 2018 hingga saat ini. Berdasarkan hasil observasi terhadap mahasiswa yang telah menempuh mata kuliah data minng dan wawancara yang dilakukan oleh pengembang terhadap dosen pengampu matakuliah data mining menyatakan bahwa sumber belajar telah tersedia, akan tetapi masih belum lengkap dan sesuai. Sehingga dibutuhkan sesuatu yang baru untuk membantu proses pembelajaran yang sesuai dengan kompetensi pada matakuliah data mining di Jurusan Teknk Elektro Universitas Negeri Malang (Baker, 2010).

Hal ini dikarenakan sumber ajar yang masih bersifat sederhana dalam artian hanya sebatas menggunakan rangkaian gambar pada presentasi,buku referensi yang masih kurang dalam penyajian materi, dan keterangan-keterangan tambahan maupun simulasi manual yang digambarkan di papan tulis (Mustafidah, 2016). Tentunya hal ini tidak sesuai dengan materi data mining yang memiliki gaya belajar visual-kinestetis Akibatnya situasi kelas pada pembelajaran menjadi tidak praktis, kurang menarik serta membosankan, bahkan menjadi sangat ketergantungan dengan kehadiran dosen. Sehingga perlu mencari alternatif lain agar pembelajaran menjadi lebih menarik dan mahasiswa menjadi lebih mudah dalam menerima materi yang telah disampaikan serta membantu pembelajaran dan praktikum secara mandiri agar mengurangi efek ketergantungan kehadiran pengajar (Marthasari, 2017).

Berdasarkan hasil observasi wawancara kepada dosen pengampu, hal ini menjadi lebih urgensi dikarenakan dosen pengampu akan menempuh studi jenjang di luar negeri, sehingga akan lebih sulit dalam menyampaikan pembelajaran. Berdasarkan latar belakang masalah diatas, maka perlu dirancang pengembangan sumber belajar pada matakuliah Data Mining. Dengan adanya sumber belajar yang dikembangkan diharapkan dapat menambah pemahaman, mematangkan konsep, dan analisis mahasiswa dalam proses pembelajaran. Maka pengembang mengajukan penelitian dengan konsep pengembangan sumber belajar yang berjudul "Pengembangan Bahan Ajar Matakuliah Data Mining menggunakan RapidMiner pada Jurusan Teknik Elektro UM (Romero \& Ventura, 2013).

\section{METODE}

Metode penelitian dan pengembangan digunakan untuk menghasilkan dan menguji keefektifan dari suatu produk (Sugiyono, 2018). Terdapat banyak macam model penelitian yang digunakan pada penelitian pengembangan, namun setiap model tersebut dapat dipilih berdasarkan tingkat penggunaannya atau jumlah langkah pada setiap tahap. Sehingga penyusunan bahan ajar harus memperhatikan kebutuhan dilapangan dan sesuai dengan kaidah langkah penyusunan yang tepat (Suhartati \& Gipayana, 2017). Pada penelitian ini format model penelitian dan pengembangan yang digunakan adalah 4D. Model pengembangan 4D merupakan model pengembangan yang terdiri dari empat tahapan utama yaitu; 1) Define 2) Design 3) Develop 4) Disseminate (Trianto, 2010). Metode dan model ini dipilih berdasarkan tujuan penelitian untuk menghasilkan produk berupa bahan ajar mata kuliah data mining Gambar 1.

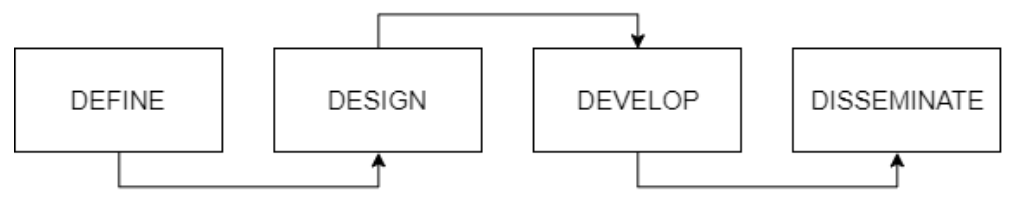

Gambar 1. Model Pengembangan 4D

\section{Define}

Proses ini dilakukan untuk menetapkan dan mendefinisikan syarat dari proses pengembangan. Dalam proses yang berbeda, proses ini dinamakan analisis kebutuhan. Tiap-tiap produk tentu membutuhkan analisis 
yang berbeda-beda. Secara umum, dalam pendefinisian ini dilakukan kegiatan analisis kebutuhan pengembangan, syarat-syarat pengembangan produk yang sesuai dengan kebutuhan pengguna serta model penelitian dan pengembangan (model R\&D) yang cocok untuk mengembangkan produk. Analisis dilakukan melalui studi literatur atau penelitian pendahuluan. Analisis kurikulum, karaketristik peserta didik, materi dan perumusan tujuan adalah kegiatan yang dilakukan pada tahap define ini (Thiagarajan et al., 1974).

\section{Design}

Design atau perancangan adalah tahap yang bertujuan untuk mempersiapkan rancangan awal dari suatu produk. Pada model 4D tahap design terbagi dalam empat kegiatan, yaitu: constructing criterionreferenced test, media selection, format selection, initial design. Constructing criterion-referenced test atau penyusunanan kriteria tes merupakan Langkah penghubung proses define dan design, dimana pada langkah ini indikator pencapaian kompetensi dipecah dan disajikan menjadi beberapa tujuan pembelajaran. Selanjutnya pada tahap media selection atau pemilihan media merupakan tahap penentuan media yang dihasilkan pada pengembangan. Setelah menentukan media yang digunakan, tahap selanjutnya adalah format selection atau pemilihan format. Pada tahap ini media yang telah dipilih pada produk akan ditentukan formatnya. Tahap terakhir adalah initial design atau rancangan awal, merupakan langkah rancangan awal yang akan diterapkan pada produk ini.

\section{Develop}

Developmental testing pengujian rancangan produk pada sasaran subjek yang sebenarnya. Pada uji coba ini dicari data respon dari sasaran pengguna model. Pada proses pengembangan bahan ajar ini, uji konten dan modul dilakukan oleh para ahli yang telah dipilih pada proses validasi konsep, dan modul yang akan digunakan oleh para siswa (Fajarini, 2018). Hasil tes akan direvisi sehingga dapat dipakai untuk memenuhi kebutuhan para pengguna. Efisinsi penggunaan modul penting dilakukan untuk meningkatkan hasil belajar. Kemudian dilanjutkan dengan memberikan soal yang isinya didapat dari modul yang sudah dikembangkan. Cara untuk mengembangkan modul dengan menguji isi dari modul yang dilakukan oleh para ahli yang terlibat dalam proses validasi yaitu ahli media dan materi.

\section{Disseminate}

Dalam 4D, siaran dibagi menjadi tiga kegiatan, yaitu: tes validasi, pengemasan, menyebarkan dan mengadopsi. Dalam uji validasi, produk yang telah direvisi pada proses pengembangan ditujukan pada target yang telah ditentukan, ini penting dilakukan untuk menentukan efisiensi produk yang dikembangkan. Setelah produk diimplementasikan, akan dapat dilihat hasilnya. Tujuan yang tidak dapat dicapai harus disimpulkan bagaimana caranya agar tidak mengulangi kesalahan yang sama sebelum produk tersebut di sebar-luaskan. Aktivitas terakhir dari fase pengembangan adalah melakukan proses pengemasan, diseminasi dan adopsi. Langkah ini dilakukan agar produk dapat digunakan oleh orang lain. Pengemasan modul ini dapat dibuat dengan mencetak buku atau aplikasi. Setelah buku dicetak, lalu dibagikan sehingga dapat digunakan oleh orang lain. Dalam proses pengembangan bahan ajar, fase diseminasi dilakukan dengan distribusi dalam jumlah terbatas pada pendidik dan siswa dan dimaksudkan untuk mendapatkan respons. Apabila respons pengguna baik, maka dapat dilakukan pencetakan dalam skala besar dan dilanjutkan dengan proses pemasaran, sehingga memiliki target yang lebih luas. Pada tahap ini, distribusi dilakukan oleh dosen mata kuliah data mining.

Data yang didapat dalam penelitian ini adalah data kuantitatif dan kualitatif. Data kuantitatif pada penelitian ini adalah penilaian media dari hasil angket yang disebarkan kepada ahli media dan ahli materi sebagai validator sehingga angket tersebut akan diperoleh data dengan perhitungan skor jawaban. Sedangkan data kualitatif yang dimaksud dalam pengembangan ini diperoleh dari tanggapan berupa kritik maupun saran dari ahli media dan ahli materi. Mengukur suatu variabel diperlukan alat ukur yang biasa disebut instrumen Dalam studi tentang pengembangan data menggunakan observasi, wawancara dan penyebaran kuesioner. Kuesioner digunakan untuk menghitung kelayakan modul yang telah dikembangkan. Kuesioner terdiri dari aspek konten, karakteristik, fungsi dan aspek grafik. Kuesioner diberikan kepada para ahli media dan pakar materi.

Mengukur suatu variabel diperlukan alat ukur yang biasa disebut instrumen. Para ahli psikometri telah menetapkan kriteria bagi alat ukur, seperti instrumen, untuk dinyatakan sebagai alat ukur yang baik 
(Azwar, 2011). Secara umum yang dimaksud dengan instrumen adalah suatu alat yang karena memenuhi persyaratan akademis maka dapat dipergunakan sebagai alat untuk mengukur suatu obyek ukur atau mengumpulkan data mengenai suatu variabel (Djaali \& Muljono, 2007). Dalam penerapannya instrumen terdapat dua macam yaitu tes dan non-tes, yang termasuk kelompok tes, seperti tes prestasi belajar, tes intelegensi, tes bakat; sedangkan yang termasuk tes, kelompok non-tes seperti pedoman wawancara, angket atau kuesioner,lembar observasi, daftar cocok (check list), skala sikap, skala penilaian, dan lainnya. Dalam penelitian dan pengembangan ini metode pengumpulan data yang digunakan adalah jenis angket (rating scale). Angket rating scale adalah kuesioner yang berisikan pertanyaan diikuti kolom-kolom yang menunjukan tingkatan-tingkatan (Arikunto, 2013). Angket tersebut digunakan untuk pengumpulan datadata kuantitatif dengan menggunakan skala likert (Tabel 1)

\begin{tabular}{|c|c|}
\hline Skor & Keterangan \\
\hline 4 & Sangat setuju / sangat baik / sangat layak / sangat sesuai \\
\hline 3 & Setuju / baik/ layak/ sesuai \\
\hline 2 & Cukup setuju / cukup baik / cukup layak / cukup sesuai \\
\hline 1 & Tidak setuju / tidak baik / tidak layak / tidak sesuai \\
\hline
\end{tabular}
Sumber: Arikunto (2013)

Tahapan dalam penyusunan instrumen dimulai dari menentukan indikator instrumen penelitian, menjabarkan indikator ke dalam bentuk butir-butir instrumen penelitian. Instrumen penelitian kemudian akan dikonsultasikan terlebih dahulu kepada ahli untuk diperbaiki dan disempurnakan. Teknik analisis data yang akan digunakan tentunya akan dibedakan sesuai dengan jenis data yang didapatkan. Untuk data kualitatif diperoleh dari kritak dan saran yang didapatkan sdan dianalisis secara deskriptif, sedangkan data kuantitatif diperoleh dari skor angket dan kemudian dianalisis menggunakan teknik presentase dengan melihat kriteria validitas yang digunakan. Berikut merupakan rumus yang digunakan dalam menganalisis hasil angket responden dan observer, responden ahli media dan ahli materi.

$$
V a=\frac{T S e}{T S h}
$$

\section{Keterangan : \\ Va : Validasi ahli \\ TSe $\quad$ : Total skor empiris (hasil jawaban responden secara keseluruhan) \\ TSh $\quad$ : Total skor harapan (hasil skor maksimal secara keseluruhan)}

Rumus gabungan validasi ahli media dan validasi ahli materi.

Keterangan :

$$
V_{\text {gabungan }}=\frac{V_{\text {media }}+V_{\text {materi }}}{2}
$$

Vgabungan : Validasi gabungan dari ahli media dan ahli materi

Vmedia : Nilai validasi dari ahli media

Vmateri $\quad$ : Nilai validasi dari ahli materi Tabel 2.

Hasil dari penilaian dapat diketahui kelayakannya sesuai format kriteria kelayakan modul dengan

Tabel 2. Kriteria Kelayakan Modul

\begin{tabular}{ccc}
\hline $85,01 \%-100 \%$ & Media sangat baik/ sangat layak & Dapat digunakan tanpa revisi \\
$70,01 \%-85,00 \%$ & Baik/layak & Dapat digunakan dengan revisi kecil \\
$50,01 \%-70,00 \%$ & Cukup baik/cukup layak & Dapat digunakan setelah dilakukan revisi besar \\
$01,00 \%-50,00 \%$ & Kurang baik/kurang layak & Tidak dapat digunakan \\
\hline
\end{tabular}

Sumber : (Akbar \& Hartono, 2017) 
HASIL DAN PEMBAHASAN

\section{Define}

Pada tahapan define atau pendefinisian bertujuan untuk menganalisis kebutuhan produk. Dalam penelitian ini analisis kurikulum yang digunakan adalah berdasarkan katalog yang berbasis pada kurikulum pembelajaran berbasis kehidupan (life-based learning). Berdasarkan hasil observasi wawancara yang dilakukan kepada mahasiswa yang telah menempuh mata kuliah data mining, ditemukan kecenderungan bahwa mahasiswa tidak mampu memahami mata kuliah data mining dikarenakan kurangnya sumber bahan ajar akan materi data mining serta pengaplikasiannya menggunakan tool terkait.

Materi yang dimuat dalam bahan ajar telah disesuaikan dengan analisa kurikulum pada tahapan sebelumnya, diantaranya yaitu: 1). Pengantar Data Mining 2). Explores Data 3). Visualisasi Data 4). Algoritma Klasifikasi 5). Evaluasi Klasifikasi 6). Klasifikasi Ensemble 7). Preprocessing 8). Klasterisasi 9). Asosiasi. Budaya literasi yang diterapkan pada Jurusan Teknik Elektro Universitas Negeri Malang memungkinkan bahan ajar sangat berpotensi untuk dikembangan. Penelitian dan pengembangan ini bertujuan untuk merancang dan membuat bahan ajar. Hal tersebut dilihat dengan kurang adanya bahan ajar yang dapat diakses secara mandiri untuk menunjang dan menumbuhkan kesiapan belajar peserta didik pada mata kuliah Data Mining.

\section{Design}

Tahap design (perancangan) bertujuan untuk mempersiapkan rancangan awal produk. Menurut Thiagajaran terdapat empat langkah pada tahapan ini, yaitu penyusunan kriteria tes, pemilihan media, pemilihan format dan rancangan awal. Pada tahap penyusunan kriteria tes ini, peneliti memecah indikator pencapaian kompetensi menjadi beberapa tujuan pembelajaran pada setiap materi. Tujuan pembelajaran yang telah dipecah pada setiap materi disajikan sebagai latihan dan tugas yang terdapat pada tiap modul materi. Setelah menyusun kriteria tes, tahap selanjutnya yang telah dilakukan peneliti adalah pemilihan media. Dimana dalam perancangannya media yang digunakan adalah bahan ajar berupa modul cetak. Modul cetak tersebut dilengkapi dasar teori yang sesuai dengan materi pada setiap babnya, serta latihan yang menggunakan alat terkait (dalam hal ini adalah rapidminer) dan tugas sebagai penunjang pemahaman materi.

Tahap yang dilakukan peneliti setelah penentuan media, adalah pemilihan format. Pada tahap ini format yang digunakan oleh peneliti pada media adalah format yang berpedoman dari BNSP (Badan Standar Nasional Pendidikan) yang telah dimodifikasi sesuai dengan kebutuhan peneliti. Langkah akhir dari tahap perancangan adalah rancangan awal (initial design) yang bertujuan untuk membuat desain awal dari produk ini. Berdasarkan tahapan pemilihan format sebelumnya, maka dapat diperoleh desain awal berupa ukuran, warna dan sistematika.

Pada bahan ajar cetak ini ukuran kertas yang digunakan adalah A4, dengan menggunakan jenis huruf Times New Roman berukuran 12 poin pada isinya dan berukuran 14 poin pada subbabnya, serta menggunakan paragraph spasi berukuran 1,5. Warna tulisan yang digunakan pada tiap materi babnya adalah warna hitam dengan latar belakang berwana putih. Sementara pada bagian header dan footer menggunakan paduan warna jingga, abu-abu dan hitam. Paduan warna tersebut dipilih berdasarkan paduan warna yang terdapat pada logo RapidMiner pada gambar 2.1. Selain ukuran dan warna juga terdapat susunan sistematika penulisan pada tiap babnya, untuk menunjang pemahaman peserta didik. Sistematika penulisan ini meliputi judul bab, tujuan pembelajaran, petunjuk penggunaan, materi, latihan, praktikum atau tugas yang susunannya dapat dilihat pada ilustrasi Gambar 2. 


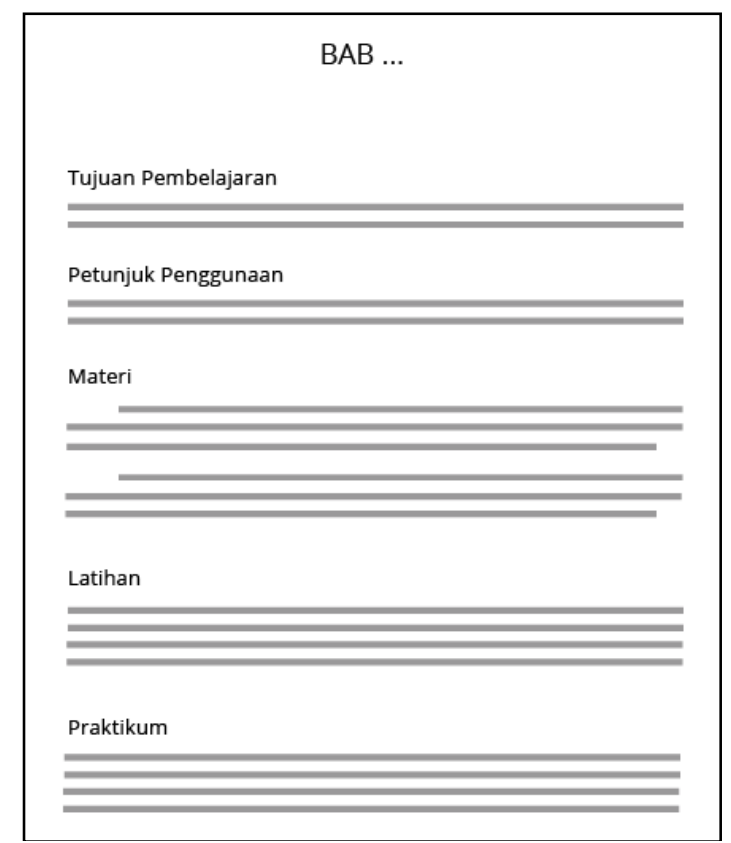

Gambar 2. Susunan tataletak

\section{Develop}

Hasil dari pengembangan bahan ajar ini merupakan modul dalam bentuk cetak. Materi pada modul ini dikembangkan dari standar kompetensi berdasarkan katalog jurusan teknik elektro 2019 yang berbasis pada penerapan kurikulum berbasis kehidupan (life-based learning). Instruksi pada modul disesuaikan dengan metode pembelajaran CDIO sehingga mendukung penerapan kurikulum yang sedang berlaku. Struktur modul terbagi menjadi dua bagian, yaitu materi bahan ajar dan komponen kelengkapan bahan ajar.

\section{Materi bahan ajar}

Materi pada bahan ajar data mining ini dijabarkan pada peta konsep materi bahan ajar. Peta konsep materi bahan ajar berisi peta konsep yang memaparkan struktur materi pada matakuliah data mining dan keterkaitan antar materi. Desain peta konsep materi pada bahan ajar dapat dilihat pada Gambar 3.

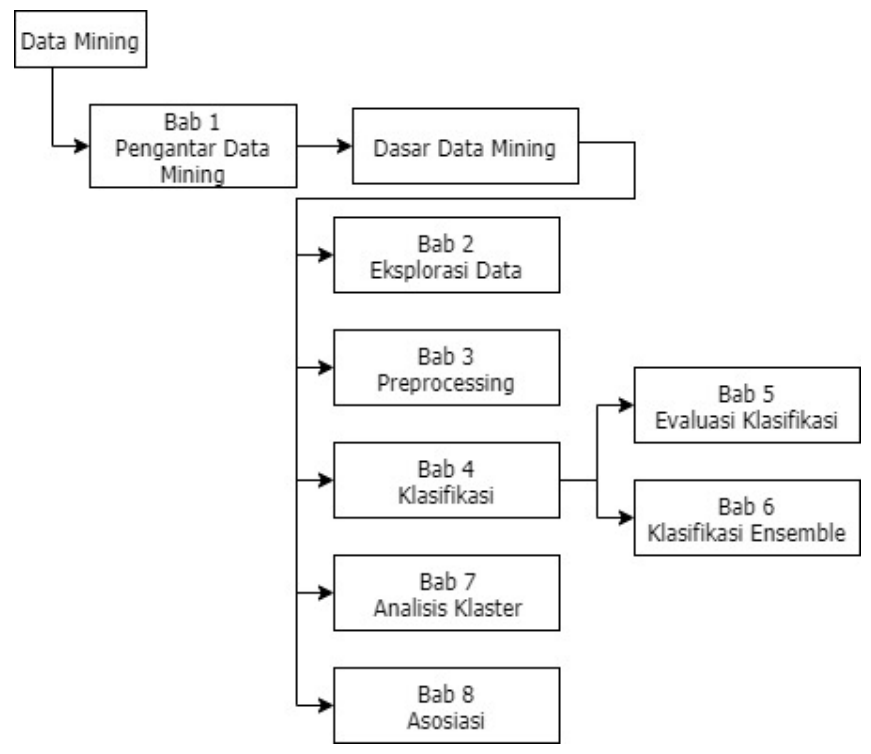

Gambar 3. Peta Konsep Materi Bahan Ajar 


\section{Komponen kelengkapan bahan ajar}

Komponen kelengkapan bahan ajar data mining ini meliputi: (1) sampul; (2) kata pengantar; (3) daftar isi; (4) petunjuk penggunaan bahan ajar; dan (5) langkah-langkah penyelesaian masalah; (6) catatan kaki dan daftar pustaka. Halaman sampul bahan ajar merupakan bagian terluar. Pada halaman ini terdapat judul bahan ajar dan ilustrasi data mining. Pada desain halaman sampul, jenis huruf yang digunakan adalah Oswald dengan paduan warna teks pada judul abu-abu tua dan jingga dengan latar belakang berwarna abuabu, sehingga keseluruhan warna yang digunakan pada sampul ini adalah abu-abu tua, abu-abu dan jingga. Pemilihan warna yang digunakan dalam teks judul dan keterangan berdasarkan dengan logo rapidminer. Begitupun pemilihan warnapun pada ilustrasi gambar yang digunakan dibawah judul juga sama sehingga terlihat lebih menarik. Ilustrasi gambar yang digunakan pada sampul, terutama persegi berwarna jingga merupakan representasi dari data sehingga bila dijabarkan secara umum ilustrasi dibawh judul memberikan representasi seorang peneliti yang sedang mengelola data Gambar 4.

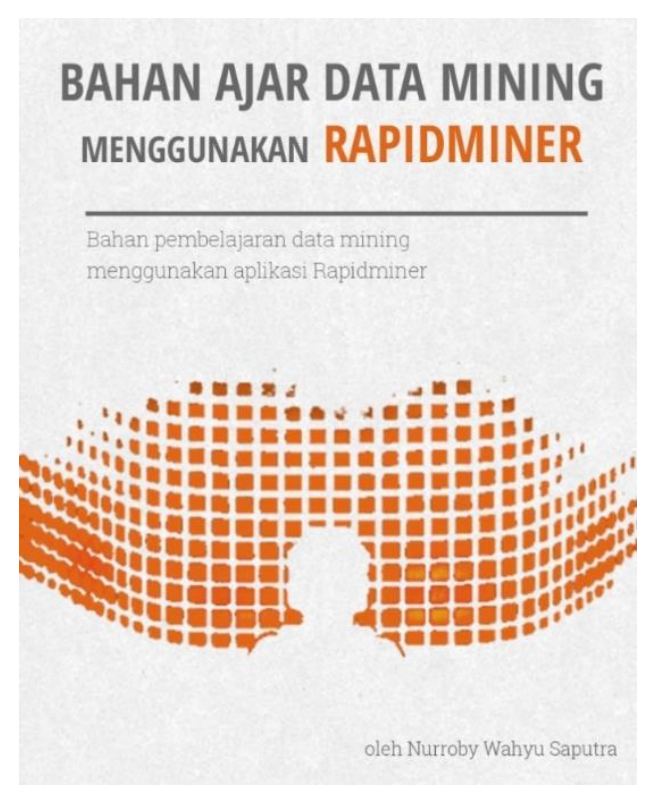

Gambar 4. Desain sampul bahan ajar

Setelah halaman sampul bahan ajar terdapat kata pengantar yang berisi pesan-pesan pengembangan bahan ajar dari penulis kepada pembaca bahan ajar. Kemudian pada bagian daftar isi berisi informasi mengenai daftar materi beserta latihan dan studi kasus yang dilengkapi dengan nomor halaman. Berisi petunjuk penggunaan bahan ajar, dimana terdapat bahan atau alat yang perlu dipersiapkan sebelum mengimplementasikan materi data mining. Setelah itu, akan disajikan tabel yang berisi penjelasan melaksanakan pembelajaran sesuai dengan langkah-langkah CDIO. Pada penjelasan tabel penyelesaian masalah, dibagi menjadi empat komponen utama CDIO. Setelah itu, setiap komponen diberikan penjelasan dalam langkah-langkah penyelesaian. Langkah-langkah penyelesaian tersebut dapat dilihat pada Tabel 3.

Tabel 3. Langkah-langkah Penyelesaian Masalah Secara CDIO

\begin{tabular}{cll}
\hline Komponen CDIO & & \multicolumn{1}{c}{ Langkah-langkah penyelesaian } \\
\hline Conceive & 1. & Membaca dan memahami permasalahan. \\
& 2. & Identifikasi pra dan post kondisi dari masalah. \\
Design & 3. & Menentukan beberapa solusi yang mungkin pada masalah. \\
& 4. & Analisis detail permasalahan. \\
Implementation & 5. & Tentukan solusi terbaik pada permasalahan. \\
& 6. & Implementasikan menggunakan tools yang terdapat pada program. \\
Operate & 7. & Uji coba program \\
& 8. & Menampilkan dan uji coba dengan instruktur disertai perubahan pada program untuk menguji \\
& & program sudah berjalan efektif atau belum. \\
\hline
\end{tabular}


Pada bagian ini akan diberikan contoh penyelesaian masalah ataupun studi kasus sesuai dengan langkah-langkah CDIO. Langkah-langkah penyelesaian ini disesuaikan dengan petunjuk penggunaan bahan ajar yang telah dijelaskan sebelumnya. Setiap langkah penyelesaian, direpresentasikan dalam bentuk symbol yang mewakili setiap komponen CDIO. Simbol yang digunakan disesuaikan dengan arti atau makna setiap tahapan CDIO. Simbol-simbol yang digunakan tersebut dapat dilihat pada Gambar 5.

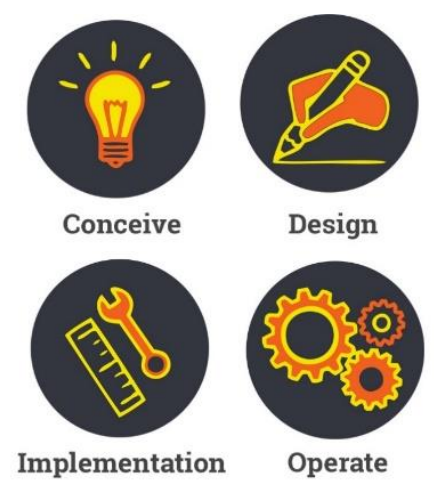

Gambar 5. Simbol-simbol CDIO pada bahan aar

Simbol-simbol yang mewakili penjelasan sebagai berikut:

1. Conceive, memahami permasalahan dari materi, latihan maupun tugas yang diberikan.

2. Design, merancang solusi untuk permasalahan yang akan diselesaikan.

3. Implementation, membuat desain program dari rancangan solusi yang dibuat.

4. Operate, mempresentasikan solusi pada instruktur dan peserta didik yang lain untuk menguji program telah berjalan efektif ataupun belum.

Berisi latihan dan tugas yang harus diselesaikan oleh mahasiswa. Latihan dan tugas yang disajikan tidak hanya berasal dari bahan ajar yang dikerjakan oleh mahasiswa, melainkan terdapat tautan dari sumber lain yang mengharuskan mahasiswa harus mengeksplorasi ke sumber yang berbeda. Pada setiap latihan atau tugas terdapat simbol-simbol CDIO sebelumnya untuk menentukan lankah apa saja yang perlu dilakukan pada setiap latihan atau studi kasus. Contoh dari lembar latihan dan tugas dapat dilihat pada Gambar 6.

\section{Latihan}

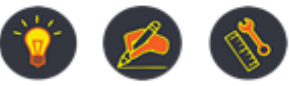

1. Buka laman https://www.youtube.com/watch?v=sDg7U16VPrU. Amati dan praktikan teknik preprocessing aggregation pada video ini.

2. Implementasikan teknik preprocessing aggregation menggunakan data titanic menggunakan RapidMiner.

Tugas

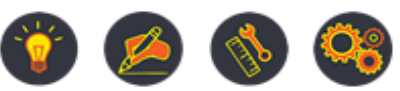

1. Cari dataset pada laman https://data.go.id atau https://kaggle.com,

2. Pilih dua dataset yang akan digunakan (masing-masing mahasiswa harus berbeda dataset)

3. Analisa kebutuhan dan Implementasikan teknik preprocessing pada dataset tersebut

Gambar 6. Contoh latihan dan tugas 
Catatan kaki yang digunakan pada bahan ajar ini berfungsi sebagai referensi yang digunakan untuk menunjukkan sumber dari pernyataan yang dipergunakan pada setiap halaman. Sementara daftar pustaka digunakan sebagai pelengkap dari catatan kaki dan diletakkan pada akhir bahan ajar ini, hal ini bertujuan untuk membantu pembaca mengetahui referensi lebih lengkap yang terdapat pada catatan kaki. Setelah melalui tahapan penyusunan bahan ajar diatas proses yang perlu dilakukan adalah validasi dan ujicoba produk. Proses validasi dan ujicoba produk dilakukan untuk mengetahui tingkat validitas produk sebelum dilakukan disseminate. Adapun proses validasi dan ujicoba produk ini berupa uji terbatas kepada ahli materi dan ahli media.

Validasi ahli materi menggunakan instrumen angket sebanyak 21 butir pertanyaan. Dari 21 butir pertanyaan tersebut dibagi menjadi tiga aspek penilaian yaitu aspek kelayakan isi bahan ajar dan kelayakan penyajian bahan ajar. Validasi materi dilaksanakan pada tanggal 16 Juli 2020, dan dilakukan oleh bapak Harits Ar Rosyid, S.T., M.T., Ph.D. yang memiliki keahlian dibidang keilmuan sejenis yaitu machine learning. Data yang diperoleh dari hasil validasi dihitung menggunakan persamaan (1) yang dikemukakan oleh Akbar dan Hartono. Hasil dari validasi ahli media terhadap bahan ajar dapat dilihat pada tabel 4.

Tabel 4. Hasil Validasi Ahli Materi

\begin{tabular}{ccc}
\hline Aspek & Presentase Validitas & Keterangan \\
\hline Kelayakan isi bahan ajar & $87,5 \%$ & Sangat Layak \\
Kelayakan penyajian bahan ajar & $75 \%$ & Layak \\
\hline
\end{tabular}

Berdasarkan perhitungan diatas didapatkan hasil presentase validitas kelayakan isi bahan ajar sebesar $87,5 \%$. Sehingga dapat disimpulkan bahwa kelayakan isi dari bahan ajar ini dalam dikategorikan sangat layak. Sementara hasil berbeda didapatkan dalam aspek kelayakan penyajian bahan ajar, dengan presentase validitas sebesar $75 \%$. Hal ini disebabkan karena kurangnya contoh yang terdapat pada beberapa materi data mining, yang memang dalam realitanya belum dapat ditemukan contohnya pengaplikasiannya pada rapidminer. Terdapat pula sedikit catatan dari ahli mater berupa saran agar terdapat penguatan konten berupa screenshot pada beberapa materi yang memang dirasa sulit. Sehingga bila dilihat dari segi segi materi, bahan ajar dikategorikan sangat layak bila ditinjau dari aspek kelayakan bahan ajar namun diperlukan revisi kecil pada aspek kelayakan penyajian bahan ajar.

Validasi ahli media menggunakan instrumen angket yang terdiri dua aspek penilaian yaitu kelayakan bahasa bahan ajar dan kelayakan kegrafisan. Kedua aspek tersebut diuraikan dalam 26 butir pertanyaan. Validasi media dilakukan pada tanggal 15 Juli 2020 dengan ahli media yang dipilih dalam penelitian ini adalah bapak Ilham Ari Elbaith Zaeni, S.T., M.T., Ph.D. yang memiliki pengalaman sebagai reviewer dalam ICEEIE pada tahun 2017. Data yang diperoleh dari hasil validasi dihitung menggunakan persamaan (1) yang dikemukakan oleh Akbar dan Hartono. Hasil dari validasi ahli media terhadap bahan ajar dijabarkan pada Tabel 5 .

Tabel 5. Hasil Validasi Ahli Media

\begin{tabular}{ccc}
\hline Aspek & Presentase Validitas & Keterangan \\
\hline Aspek Kelayakan Bahasa Bahan Ajar & $88,8 \%$ & Sangat Layak \\
Aspek Kelayakan Kegrafisan Bahan Ajar & $91,1 \%$ & Sangat Layak \\
\hline
\end{tabular}

Berdasarkan perhitungan diatas didapatkan hasil presentase validitas kelayakan bahasa bahan ajar sebesar 88,8\%. Sehingga dapat disimpulkan bahwa kelayakan bahasa dari bahan ajar ini dalam dikategorikan sangat layak. Sementara hasil yang lebih tinggi didapatkan pada aspek kelayakan kegrafisan bahan ajar, dengan presentase validitas sebesar $91,1 \%$. Dengan hasil nilai yang didapatkan dari kedua aspek dapat disimpulkan bahwa bahan ajar dapat dikategorikan sangat layak dalam aspek kelayakan bahasa bahan ajar serta sangat layak pada aspek kelayakan kegrafisan bahan ajar. Meskipun bahan ajar dikategorikan sangat layak namun terdapat sedikit catatan dari ahli media berupa saran agar ditambahkan media penyimpanan berupa CD untuk bahan ajar untuk menanggulangi resiko kehilangan video penunjang materi. 


\section{Disseminate}

Tahapan diseminasi (disseminate) merupakan tahapan terakhir dalam model pengembangan 4D. Tahapan diseminasi bertujuan untuk memperkenalkan bahan ajar yang yang telah divalidasi dan direvisi kepada instruktur atau dosen pengampu matakuliah data mining. Berdasarkan hasil yang didapat dari dua subyek ujicoba yang terdiri dari ahli media dan materi maka dapat dihitung hasil validasi produk berdasarkan gabungan penilaian dari kedua ahli menggunakan persamaan (2) adalah $85,375 \%$ yang berarti nilai produk dalam kategori sangat layak. Sehingga bila nilai produk dilihat berdasarkan tabel 3.3 maka bahan ajar ini dapat digunakan tanpa revisi, namun diperlukan beberapa revisi kecil pada penyajian bahan ajar sesuai dengan materi dan gaya belajar mahasiswa. Berdasarkan hasil penelian tersebut maka produk bahan ajar ini dapat langsung diseminasikan, hasil diseminasi yang telah dilakukan peneliti melalui penyerahan produk dan wawancara kepada dosen pengampu matakuliah, didapatkan hasil tanggapan bahwa materi pada bahan ajar dikategorikan baik dengan tambahan perlu penguatan pada beberapa materi dan penambahan materi dalam kategori intermediate, agar terbentuk bahan ajar data mining yang lebih baik lagi”.

\section{SIMPULAN}

Berdasarkan tujuan pengembangan produk berupa bahan ajar matakuliah data mining, dapat disimpulkan bahwa produk berupa bahan ajar cetak matakuliah data mining telah dikembangkan dan diuji validitasnya. Produk yang dikembangkan telah melalui serangkaian proses dalam model pengembangan 4D. Dimulai dari pendefinisian dengan melakukan serangkaian kegiatan analisis kurikulum, analisis karakteristik peserta didik, analisis materi, analisis lingkungan belajar, serta perumusan tujuan. Pada tahap perancangan produk ini juga telah melalui beberapa proses diantaranya pemilihan media, penyusunan kriteria tes, pemilihan format, hingga rancangan awal. Dalam tahap pengembangan, produk yang pada tahapan sebelumnya telah dirancang, disusun komponen kelengkapan bahan ajar serta materinya juga diuji validasinya. Uji validasi yang dilakukan melibatkan ahli materi dan ahli media menghasilkan produk dengan presentase validitas $85,375 \%$ serta dikategorikan sangat layak sehingga penyebarluasan dapat dilakukan kepada instruktur/dosen pengampu matakuliah data mining. Selain dikembangkan dengan menggunakan model pengembangan 4D produk ini memuat metode pembelajaran CDIO yang menekankan pada ilmu-ilmu keteknikan dasar sehingga pembaca diarahkan berpikir secara logis dan bertindak secara sistematis. Berdasarkan hasil validasi dari ahli materi, dapat disimpulkan bahwa materi yang ada dalam bahan ajar matakuliah data mining, telah sesuai dengan Kompetensi Dasar yang terdapat pada katalog kurikulum 2019 TE UM dan tujuan metode pembelajaran CDIO, sedangkan berdasarkan hasil validasi dari ahli media telah layak untuk.

\section{DAFTAR RUJUKAN}

Akbar, F. I., \& Hartono, R. (2017). Pengembangan lembar kegiatan peserta didik dengan model pengembangan 4-d pada materi mitigasi bencana dan adaptasi bencana kelas X SMA. Jurnal Pendidikan Geografi, 22(2), $135-147$. https://doi.org/10.17977/um017v22i22017p135

Arikunto, S. (2013). Dasar-dasar evaluasi pendidikan. Bumi Aksara.

Azwar, S. (2011). Tes prestasi: Fungsi dan pengembangan pengukuran prestasi belajar. Pustaka Belajar.

Bahtiar, E. T. (2015). Penulisan bahan ajar. In Pelatihan Penyusunan Bahan Ajar untuk Mendukung Pelaksanaan Tri Dharma Perguruan Tinggi (pp. 1-11).

Baker, R. S. J. D. (2010). Data mining for education. International Encyclopedia of Education, 7(3), 112-118.

Djaali, H., \& Muljono, P. (2007). Pengukuran dalam bidang pendidikan. PPS UNJ.

Fajarini, A. (2018). Pengembangan bahan ajar IPS. Syair Gema Maulana.

Jurusan Teknik Elektro. (2019). Buku pedoman akademik program studi Teknik Informatika tahun akademik $2019 / 2020$. UM Press.

Marthasari, G. I. (2017). Implementasi teknik Data Mining untuk evaluasi kinerja mahasiswa berdasarkan data akademik. Fountain of Informatics Journal, 2(2), 20-27.

Mustafidah, H. (2016). Model regresi Data Mining motivasi belajar pengaruhnya terhadap tingkat kedisiplinan mahasiswa. JUITA: Jurnal Informatika, 1(1), 1-4.

Romero, C., \& Ventura, S. (2013). Data mining in education. Wiley Interdisciplinary Reviews: Data Mining and Knowledge Discovery, 3(1), 12-27. 
Sugiyono, M. (2018). Metode penelitian, kuantitatif, dan R\&D. Alfabeta.

Suhartati, S., \& Gipayana, M. (2017). Bahan pembelajaran berbasis budaya daerah istimewa Yogyakarta yang berkualitas. In Prosiding Seminar Nasional Mahasiswa Kerjasama Direktorat Jenderal Guru Dan Tenaga Kependidikan Kemendikbud, 1-6.

Thiagarajan, S., Semmel, D. S., \& Semmel, M. I. (1974). Instructional development for training teachers of exceptional children. National Center for Improvement Educational System. https://doi.org/10.1016/0022-4405(76)90066-2

Trianto, T. (2010). Model pembelajaran terpadu. Bumi Aksara. 